\title{
MAKING SPACE FOR PERFORMATIVITY: \\ PUBLICS, POWERS, AND PLACES IN A MULTI-REGISTER TOWN FESTIVAL (BONDOUKOU, CÔTE D'IVOIRE)*
}

\author{
Karel Arnaut
}

Every ritual is composed of disparate moments. The disparity presents an entire bundle of problems that we can here only begin to explore. ${ }^{1}$

\section{Introduction}

Les rites sont, avant tout, les moyens par lesquels le groupe social se réaffirme périodiquement. ${ }^{2}$

In anthropology the post-Durkheimian debate on ritual, performance, and society has spawned important insights into the heterogeneity of ritual performance, qua actors or participants, qua action or discourse, as well as in its interrelationship with society. To begin with the latter, beyond earlier reflections by Gluckman and Turner on ritual and processes of change, Fabian denounces the 'sociologization' of the concept of performance by arguing that performance is often incautiously considered as "enactment of a pre-existing script" in the same way that sociality (social praxis) is seen as guided by values and beliefs. ${ }^{3}$ More than any other performance, perhaps, festivals or public rituals have been seen as presenting "microcosmic mirror image[s] of society," ${ }^{4}$ while the task of the analyst

* This chapter is a reworked chapter of my Ph.D. thesis. I wish to thank the conveners, Bruno Boute and Thomas Småberg, as well as the other members of our workshop and the anonymous referees of Brill for their helpful comments and suggestions. For having given me the opportunity to explore the many things that go on in Sakaraboutou, I owe a large debt of gratitude to Youssouf Ouattara and his son Siedou Ouattara, mother and daughter Awa Ouattara and Bintou Ouattara, the formidable Ma Kouroubari, the late Alai Ouattara and his partner Bini Ouattara, and finally the young 'lions': Mahama Ouattara, Ladji Ouattara, Kader Ouattara and the many others who each year turn Sakaraboutou into a creative spectacle.

1 Werbner, Ritual Passage, Sacred Journey, 13; italics in original.

2 Durkheim, Les formes élémentaires de la vie religieuse, 553.

3 Fabian, Power and Performance, 13.

4 Erlmann, Nightsong, Performance, Power, and Practice, 20-1. 
has been unduly limited to the search for "monosemic links between society and performance." Instead, Fabian invites students of performance to (a) take on board negativity, i.e. "action that denies, contests, lacks commitment, or simply dissimulates," ${ }^{6}$ and (b) shed their 'political naïveté' by acknowledging that "people who perform relate to each other and to their society at large in terms of power." ${ }^{7}$ These two challenges, this chapter argues, can also help us to address the flaws and blind spots in the postDurkheimian debate on public ritual.

\section{Spatiality and Performativity after Durkheim}

The current debate has taken up the issues of negativity and politics but, I find, only to a limited extent. Several authors do indeed highlight the political relevance of rituals not only for perpetuating established orders ${ }^{8}$ but also for introducing or supporting alternative or revolutionary ones. ${ }^{9}$ As if in a late reaction to Steven Lukes, most authors reflect on the politics of ritual by looking into the enactment of power struggles in 'modern' "class-structured, conflictual, and pluralistic" societies ${ }^{10}$ as diverse as the Soviet Union, ${ }^{11}$ India after the assassination of Indira Ghandi, ${ }^{12}$ or Nazi Germany. ${ }^{13}$ In sum, seeing public rituals as loci of exerting or subverting power urges us to consider their place in systems of governance. So far this has been largely seen as restricted to societies that were for a long time said to be egalitarian, consensual, and existing in a state of equilibrium. But there are exceptions such as Murphy who, in his study of political discourse among the Mende, seeks to deconstruct the Durkheimian 'consensual native'. The latter Murphy denounces as an anodyne social actor who in public ritual and in society at large lacks "self-conscious awareness of the social order and a sense of separation from it." ${ }^{4}$

5 Erlmann, Nightsong, Performance, Power, and Practice, 20-1.

6 Fabian, Power and Performance, 16.

7 Ibid., Power and Performance, 17.

8 Bell, Ritual Theory, Ritual Practice.

9 Lane, The Rites of Rulers; Kertzer, Ritual, Politics, and Power.

10 Lukes, "Political Ritual and Social Integration," 301-2.

11 Lane, The Rites of Rulers.

12 Kertzer, Ritual, Politics, and Power, 140.

13 Ibid., 163.

14 Murphy, "Creating the Appearance of Consensus," 37. 
Gerd Baumann's post-Durkheimian reflections on ritual performance and (cultural, religious, etc.) diversity also take industrial 'plural/pluralistic' societies as their starting point, but seek application in 'non-plural societies' and serve to argue more broadly in favour of the inherent plurality of societies which have been mistakenly considered as 'non-plural.'15 Put differently, Baumann seeks to de-homogenize ritual practice by differentiating between participant groups. On the side of production (the actors) Baumann labels the different participant groups' 'ritual constituencies.' On the reception side (the audience), he distinguishes between 'modes of reception' and, related to this, between 'types of addressees' of rituals. The latter engage in communicating divergent if not conflicting 'values,' Bauman argues. ${ }^{16}$ More precisely, in the rituals and celebratory events (Christmas and birthday parties) in multicultural London, 'others' are intimately implicated in the texture of the public ritual and feature in a range of diverse participatory roles. In spite of this de-homogenising endeavour, Baumann's analysis arguably remains, to repeat Fabian's words, "politically naïve." While it takes in processes of dialectical identityconstruction in the context of public rituals, it dwells little on the wider power relations in which these are embedded. When dealing, for instance, with the participation of Muslims in Christian public rituals in a London suburb, it seems to me inevitable to address positions of marginality of e.g. Muslim migrants in the urban space versus Islam's global hegemonic aspirations. ${ }^{17}$

More recently and with reference to Baumann, Platvoet also addresses the question of public rituals in contexts of ethnic, religious, social, and cultural plurality. ${ }^{18}$ Platvoet points out that ritual occupies an often neglected place in the combat between "hostile orders whether they be political, economical, military, religious, academic, etc."19 In Platvoet's instrumental view of ritual these orders confront each other via rituals that represent or epitomize them. This is illustrated with reference to a long sequence of 'rituals of confrontation' between Hindus and Muslims

15 Cf. Baumann, "Ritual implicates 'Others'."

16 I use terms introduced by Levinson who, in response to Goffman, distinguishes between different types of "participant production roles" and "participant reception roles." Levinson, "Putting Linguistics on a Proper Footing," 169-73.

17 Baumann, "Ritual implicates 'Others'," 109. Interestingly enough, in his later work, together with Gingrich, Baumann has delved deep into the power-laden nature of processes of 'selfing and othering'; cf. Baumann and Gingrich, Grammars of Identity/Alterity.

18 Platvoet, "Ritual in plural and pluralist societies;" and "Ritual as confrontation."

19 Platvoet, "Ritual in plural and pluralist societies," 41. 
in India dating back to the middle of the previous millennium. More particularly, in the struggle over the Babri mosque in Ayodhya the clashes do not so much take place within the public rituals as with them. ${ }^{20}$ In these 'violent rituals' the political polarization seems directly proportional to the internal homogeneity of the two clashing parties, as well as to the unequivocalness of the messages they 'send' to each other. ${ }^{21}$ That is far less the case in other historical instances of 'rites of violence' such as the ones described by Natalie Zemon Davis among Catholics and Protestants in sixteenth- century France. ${ }^{22}$ Although at first sight the confrontation is a religious one, Davis detects how in these performances of street activism other groups of actors/publics are also constituted, such as that of artisans or youngsters. ${ }^{23}$ The latter participate in such large numbers, Davis argues, that it gives some of these rites the character of a generational conflict under the veil of an all too obvious religious confrontation.

Other historical instances of such contentious, laminated performances are provided by E.P. Thompson in a paper that sketches the formation of a plebeian popular culture in eighteenth-century England. ${ }^{24}$ There, the author does not so much stress the composite nature of the public as the equivocality of the messages, the multiplicity of genres, and the different tactics of voicing. In the dispersed anti-aristocratic performances which he labels 'countertheater,' Thompson faces “a world of theatrical symbolism" [which uses] an idiom (among other things) "... of oaths and of the refusal of oaths, of toasts, of seditious riddles and ancient prophecies, of oak leaves and of maypoles, of ballads with a political double-entendre, even of airs whistled in the street." ${ }^{25}$ Drawing attention to the governance situation in which this polymorphic license of the plebeian crowds thrived, Thompson concludes, that such was the price the English aristocracy and gentry had to pay in return for the joys of a restricted monarchy and a weak, decentralised state. ${ }^{26}$

20 Platvoet, "Ritual as confrontation," 213.

21 The term 'violent rituals' is Tilly's; Tilly, The Politics of Collective Violence, 81.

22 Davis, "The Rites of Violence," 59, 72 opts for the label 'rites of violence' because the latter take place "during the time of religious worship [...] and in the space which one or both groups were using for sacred purposes."

23 Ibid., 59, 87-8.

24 Thompson, "Patrician Society, Plebeian Culture." The term 'laminated' in the sense of multilayered or compartmentalized is Murphy's; Murphy, "Creating the Appearance of Consensus," 36 .

25 Thompson, "Patrician Society, Plebeian Culture," 400, italics in original.

26 Ibid., 403. 
Also in the recent anthropological literature, one can discern a few encouraging post-Durkheimian attempts to deal with ritual at the nexus of participation, voicing, and rule. In an analysis of Maurice Bloch's ritual theory, Gellner notes his typically Durkheimian stress on "the construction of order" instead of on "conflicting or 'subaltern' viewpoints" that find expression in public ritual-although Gellner does not go into much detail as to what these 'hidden transcripts' could be. ${ }^{27}$ Mitchell on the other hand, illustrates such debates and controversies, for instance between clergy and laity, in the organisation and achievement of the festa in contemporary Malta. With reference to both Baumann and Gellner, Mitchell demonstrates how ritual is a site in which "different and potentially antagonistic constituencies [...] seek to assert their agency."28

In summary, this chapter sets out to do what the above-mentioned literature has initiated, but perhaps in a more systematic way: bring elements of heterogeneity in public ritual or ritualized performance to bear on issues of power and agency. Whether in participatory roles and constituencies, multivocality or generic and stylistic choices, performance is seen as an intricate 'power play' in what David Harvey may call "governance by spectacle." ${ }^{29}$ It is far beyond the scope of this chapter to fully theorise the concept of governance by spectacle. Rather, I seek to define and illustrate two of its main conceptual elements: spatiality and performativity.

To begin with spatiality, this chapter takes its lead from David Parkin's seminal text on ritual as 'formulaic spatiality,' that is, on the power-driven dynamics of the spatial layout of ritual.

Ritually 'proper' spaces, positions, and directions may be prescribed by those in authority, but individuals can slip, if only slightly and gradually, beyond boundaries and can widen, narrow, or shift these spatial orientations. ${ }^{30}$

Here, Parkin can be seen breaking up the monolithical character of ritual performance by focussing on its inherent spatial character. Like Poppi, Smith, Fortier, Heatherington, and Regis, to name only a few, Parkin asks

27 Gellner, "Religion, Politics and Ritual", 144. The term 'hidden transcript' is obviously Scott's (as in Scott, Domination and the Art of Resistance) and not Gellner's. However, when raising the issue of subaltern viewpoints, the latter seems very much to be thinking of what Scott called infrapolitics and hidden transcripts "spoken behind the back of the dominant" (Scott, Domination and the Arts of Resistance, xii).

28 Mitchell, "Ritual Structure and Ritual Agency", 58; Baumann, "Ritual implicates 'Others';" Gellner, "Religion, Politics and Ritual."

29 Cf. Harvey, "The Political Economy of Public Space."

30 Parkin, "Ritual as Spatial Direction and Bodily Division," 19. 
attention for the contested spatiality of ritual performances by privileging ritual sequencing over ritual framing and by substituting the stress on solidity and uniformity of ritual with an interest in its often neglected fragmentation, disparity, and 'participatory discrepancies'. ${ }^{31}$ Stated otherwise, a renewed interest in the spatial features of ritual performance is connected to performativity in that it points to the diversity of expression/interpretation and identification/affirmation in ritual.

With respect to performativity, I take my lead from Lincoln who, in a restudy of the locus classicus of public rituals, the Swazi Ncwala, identified a dynamics of 'fission-fusion' whereby different groups, of variable scales and degrees of inclusivity/exclusivity, are given shape at different moments in the course of the performance. ${ }^{32}$ Underlying such a stance is the idea that people can play different roles in the same ritual, or that different groups or performative identities can be constituted by the same ritual. In accordance with the previous point, this chapter argues that such differentiation is formulated also in the spatial terms-trajectories, positions, etc. - of the performance. In other words, performative identities/positions are not 'prediscursive' or simply 'given' but partly and creatively given shape in the course of the performance. ${ }^{33}$ Such a (rather broad) take on performativity is widely established by now. ${ }^{34}$ Finally, the power-dimension of such performativity resides in the fact that, beyond any simplistic opposition between hegemony and resistance, actors can 'distance' themselves from established roles and can create or reconfigure identities or shape discourses in ways that contest or reflect on, reappropriate or subvert, existing categories, stereotypes, or statuses. ${ }^{35}$

In the analysis of the Sakaraboutou public ritual which follows, the above methodological considerations are taken on board in order to 'make space' for performativity, both in a literal and in a metaphorical sense. As to the former, this chapter suggests that in the general spatial layout as well as in the interstices of the sequences in the spatial formulation of the

31 The terms 'ritual sequencing,' 'ritual frame,' and 'disparity' are taken from Werbner, Ritual Passage, Sacred Journey, 12-3, and the concept of 'participatory discrepancies' from Keil, "Participatory Discrepancies and the Power of Music;" Poppi, 'Tenere la Piazza!'; Smith, "Where to Draw the Line;" Fortier, "Re-membering Places and the Performance of Belonging(s);" Heatherington, "Street Tactics;" Regis, "Second Lines, Minstrelsy, and the Contested Landscapes of New Orleans Afro-Creole Festivals"; Regis, "Blackness and the Politics of Memory."

32 Cf. Lincoln, "Ritual, Rebellion, Resistance."

33 Bauman and Briggs, "Poetics and Performance," 19.

34 Lloyd, "Performativity, Parody, Politics;" Hall, "Performativity."

35 Kapferer, "The Performance of Categories." 
ritual, alternative, supplementary, or conflicting articulations 'take place.' Metaphorically speaking, the conceptual space given to performativity in the analytical scheme that I shall presently try to develop is situated in between three zones: spaces/territories, emerging identities, and contested power relations. Concretely, the performativity in Sakaraboutou will be described in terms of (a) the use/creation of space and mobility, (b) the display of outfit and attributes, and (c) the production and exchange of 'text'-mostly songs, but also other genres such as stories, and religious genres such as sermons and benedictions. As I have tried to show elsewhere, these expressions form constellations of performativity, which I choose to call layers or registers. ${ }^{36}$

In performance studies — see for instance Regis ${ }^{37}$ or Schieffelin ${ }^{38}$ — the concept of register can be used in the way it was theorised in sociolinguistics, for instance by Halliday and Biber, as referring to a constellation of a specific discourse environment and the exploitation of specific linguistic features for the sake of addressing a certain audience. ${ }^{39}$ In line with this general use, Schieffelin links registers to "different subgroups or interactants" using "different media" in order to develop "multiple, differently focused points of awareness in the performance as a whole." 40 The idea of register has been developed in two more specific and influential ways: in Goffman's concept of frontstage and backstage region and in Scott's 'hidden transcript' and 'public transcript.'41 Apart from the explicit stress on the spatial allotment of performance, my concept of register borrows two other crucial aspects from both these conceptual pairs.

The first aspect is that of differential access by certain publics and the dynamics of enclosure and disclosure that ensues. Several authors have noted this as an important aspect of the frontstage-backstage concepts of Goffman. ${ }^{42}$ Also Scott indicates-although perhaps not sufficiently clearly - that access and closure in the construction of different publics

\footnotetext{
36 Arnaut, Performing Displacements and Rephrasing Attachments, 124.

37 Regis, "Second Lines, Minstrelsy, and the Contested Landscapes of New Orleans AfroCreole Festivals," 483.

38 Cf. Schieffelin, "Moving Performance to Text."

39 Halliday, "The Users and Uses of Language;" Biber, "An Analytic Framework for Register Studies." See also Agha, "Registers of Language."

40 Schieffelin, "Moving Performance to Text," 83, 85.

41 Goffman, The Presentation of Self in Everyday Life; Thompson Drewal, "The State of Research on Performance in Africa;" Scott, Domination and the Arts of Resistance; Gal, "Language and the 'Arts of Resistance'."

42 MacCannell, "Staged Authenticity," 590; Barton, "Discourse Methods and Critical Practice in Professional Communication;" Ericson, "Patrolling the Facts," 211.
} 
relates to power inequalities. ${ }^{43}$ In the analysis that follows, the three registers that I distinguish vary in degree of accessibility for the public at large and are constituted by shifting power relations both between the in- and out-group and among the in-group constituencies.

The second aspect that the present concept of register has in common with Goffman's 'regional' analysis and Scott's transcript-model is that each register is as much a spatial as a discursive construct. Goffman and several others after him have stressed how front-stage differs from backstage discourse in terms of formality or informality, solemnity or casualness. ${ }^{44}$ However, as Eliasoph convincingly shows, it would be a mistake to identify front-regions or public transcripts with formality or authoritativeness and back-regions or hidden transcripts with their opposite: with the informal or the Bakhtinian 'popular. ${ }^{45}$ Public political discourse, as shown by Mbembe in the case of Cameroon, can be grotesque and vulgar (see Stengs in this volume). ${ }^{46}$ Whatever the degree of (in)formality that distinguishes the registers we are about to analyse, the crucial point is that "back-regions appear to be fundamentally necessary social creations $[. .$.$] in situations where the front-regions they contrast with are$ high-stakes environments." 47 The high-stake environment in which the Sakaraboutou parade, which is the subject matter of this chapter, occurs is constituted by urban history and ethnic identity as well as Muslim religion. Each of the three registers that I distinguish in the Sakaraboutou parade is a spatial-discursive 'niche' with a certain degree of 'publicness,' of visibility and audibility. Each niche is the production site for the performance of certain identities/roles/personae and for the articulation as much as renegotiation of certain power inequalities between them.

\section{Making Space for Performativity:}

The Three Registers of the Sakaraboutou Public Ritual

The Sakaraboutou performance is a pageant held annually in the town of Bondoukou (Eastern Côte d'Ivoire) and closes a series of celebrations that

43 Scott, Domination and the Arts of Resistance; Gal, "Language and the "Arts of Resistance'," 417-8; Eliasoph, "Making a Fragile Public," 267.

44 Goffman, The Presentation of Self in Everyday Life, 128.

45 Cf. Eliasoph, "Making a Fragile Public."

46 Cf. Mbembe, "The Banality of Power and the Aesthetics of Vulgarity in the Postcolony."

47 Ross, "Backstage with the Knowledge Boys and Girls," 316. 
mark the end of the Muslim month of fasting (d. sungari, a. ramadan). ${ }^{48}$ Sakaraboutou takes place on the afternoon of the first day of the new month of 'drinking water' (d. mingari) — in other parts of the world also known as the 'sugar feast'-following the public prayer (d. seriba) in the morning. From two to about six p.m., a group of about 200 youngsters parade through the streets of the town. They visit many of the town's quarters and obligatorily stop off at the house of each town quarter's chief and neighbourhood imam for a greeting performance, which consists of drum music and dances. The parade ends with a final performance in front of the imam's mosque. The Sakaraboutou troupe consists of young men dressed in, among other things, traditional warrior-hunter (d. donzo) outfits. They are conducted by an elder 'chief warrior' (d. kuntigi), accompanied by a smaller group of girls dressed in what is also called a traditional outfit, who are escorted by a band of musicians (Figure 1). The Sakaraboutou girls (in the background of Figure 1) can be seen wearing the same outfit as their congeners two or three days before, at the celebration of the Night of Kouroubi (d. kurubi su). ${ }^{49}$ On this occasion, several hundreds of unmarried girls sing songs, from dusk till dawn, to brass-band music. During these long hours the girls are seated on wooden platforms of an average of three to four metres high that are put up in the different town quarters of Bondoukou.

Like other parades with religious and/or historical or memorial overtones, ${ }^{50}$ Sakaraboutou could be seen as a yearly mass-exercise in what Smith calls "claiming space and making place," which enables the Bondoukou urbanites "to think themselves into difference." 51 Such an attribution would go well with the Dyula Muslim elders, who insist on defining the identity of the city as Dyula and as Muslim, on more or less firm historical grounds.

Together with Kong, the town of Bondoukou is generally considered as one of the main places of origin of the 'Dyula.' The term 'Dyula' has an extraordinary colonial and postcolonial career whereby the ethnonym has become a political identity label which refers to a large section of

48 The abbreviations for languages spoken in Bondoukou and featuring in this paper are: d. = Dyula, and a. = Arabic. With the exception of 'Dyula,' all official names such as Kouroubi, Sakaraboutou, etc. are given in French orthography.

49 Since 1997 the Night of Destiny and Kouroubi are held separately while before that date they coincided.

50 Fortier, "Re-membering Places and the Performance of Belonging(s);" Heatherington, "Street Tactics;" Regis, "Blackness and the Politics of Memory."

51 Smith, "Where to Draw the Line," 141. 


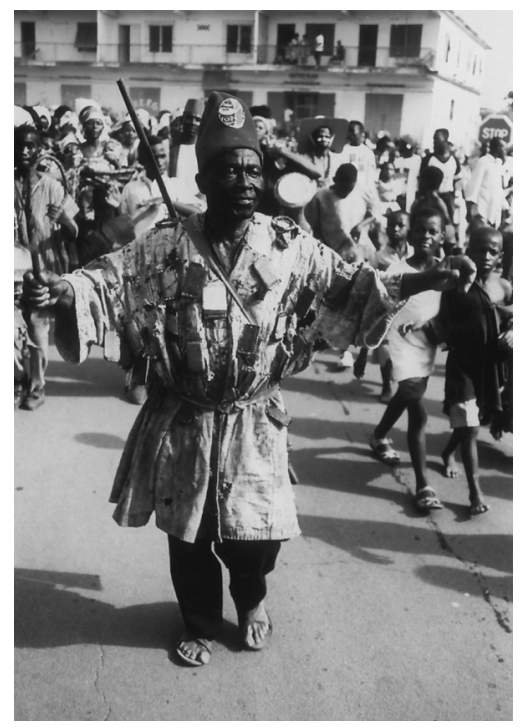

Figure 1. The chief warrior (d. kuntigi) leading the Sakaraboutou parade, accompanied by female singers and a band of male musicians (in the background) (photo by Karel Arnaut, Bondoukou, 13/03/1994).

the Ivoirian population identified as allochthones, Muslims, and travelling merchants or labourers (migrants). ${ }^{52}$ Partly related to these developments, in Bondoukou 'Dyula' has become a common denominator for all Muslims living in the city, even including the Hausa of the Malagaso town quarter.

The insistence of the Dyula elders that Sakaraboutou is the traditional festival of the whole city barely hides the fact that in the order of things that the event sustains, they themselves occupy a hegemonic position, while other groups are marginalised or simply excluded. To begin with the latter, one cannot miss the point that the parade does not call in at a number of large town quarters, notably those which are situated outside

52 'Dyula' as an ethnic-political identity in Côte d'Ivoire is characterized by a combination of at least three elements: 'northern people' associated with 'commercial activity' and 'Muslim,' Marguerat, "Des ethnies et des villes," 321; Launay and Miran, "Beyond Mande Mory," 46. A related element concerns the 'Dyula' penetration of certain 'geosocial spaces,' LeBlanc, "From Sya to Islam," 46, 89, establishing ties with other countries such as Mali and Burkina Faso, or global, tying links with the worldwide Muslim community (Launay and Miran, "Beyond Mande Mory," 46, 71). Related to such positioning, then, an exclusivist rhetoric emerged in the $1990 \mathrm{~s}$ in which the nationality of the 'Dyula' was thrown into doubt, LeBlanc, "Versioning Womanhood and Muslimhood," 447. 
the perimeter of 'traditional' Bondoukou and which happen to accommodate a majority of non-Muslim and/or non-Dyula town dwellers, partly immigrants of the rural hinterland or civil servants in residence from other parts of the country. Contrary to the modern 'commune' of Bondoukou (in which, apart from the new town quarters, a number of adjacent largely non-Muslim villages are also incorporated), the 'traditional' Bondoukou circumscribed by the Sakaraboutou parade is that 'old' part of town in which the Dyula (still) have the majority. The exception to this rule of excluding the 'traditional non-Dyula' town quarters are the neighbourhoods which are explicitly addressed as historically non-Muslim/'pagan'/Christian and which are visited at the beginning of the parade, after it has left the homestead of the Sakaraboutou chief at the Donzo quarter (d. Donzoso). As I explain elsewhere, the trajectory of the parade, beginning in the peripheral Donzoso and ending in front of the Imam's mosque (d. Limamso) in the centre of town, spans the typical categories of warriors, traders, and scholars in Mande Muslim society. ${ }^{53}$ In this configuration the 'pagan' quarters that the cortege visits at the very beginning of the parade are more associated with the peripheral and 'bush'-related Donzo hunters-warriors than with the merchants and Muslim scholars who occupy the town centre.

The 'old' (Muslim, Dyula) Bondoukou-consisting of the 'traditional' town quarters, excluding some and marking others as subaltern - forms the spatial referent of the first register in which Sakaraboutou appears as an age-old custom celebrating the historical identity and unity of the city. In this register the outfits of the main participants, 'warriors' and 'Kouroubi girls' alike, find their 'traditional' setting. The outfit of the male youngsters is a warrior's tunic (d. tunara), which consists of a shirt, a pair of trousers, and a cap. With it go offensive attributes such as old guns, spears, sticks, and knives, as well as instruments of defence such as helmets and amulets (Figure 2). The Kouroubi outfit of the girls is a combination of a glittery blouse with a 'skirt' of strip-woven cotton cloth, covered by a wealth of jewellery (a shiny belt, necklaces, and earrings, etc.) (Figure 3) Much attention is also paid to the make-up and the headdress. The latter consists of a wig with a prominent front 'chignon' (d. jomo), covered by a headscarf (d. fatara) that is kept in place by a string of multi-coloured pompons (d. gogoro, lit. 'snake'). Sunglasses and

53 Cf. Arnaut, Performing Displacements and Rephrasing Attachments; Launay, "Warriors and Traders." 


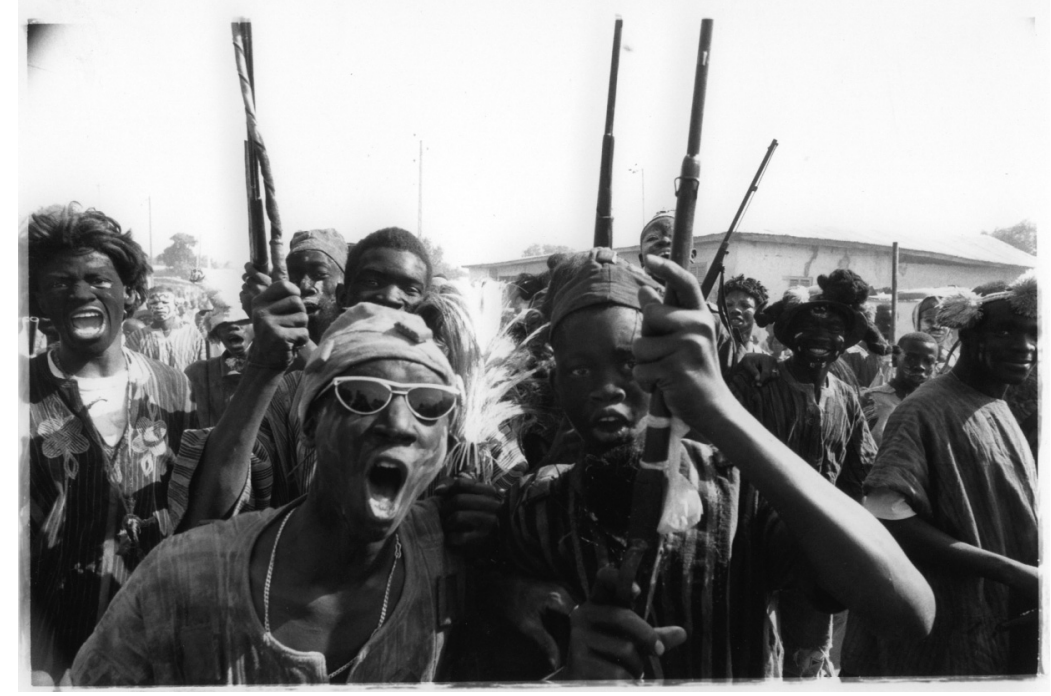

Figure 2. Male youngsters mostly in 'traditional' outfit and warrior-hunter's offensive and defensive attributes during Sakaraboutou parade (photo by Filip Erkens, Bondoukou, 9/02/1997).

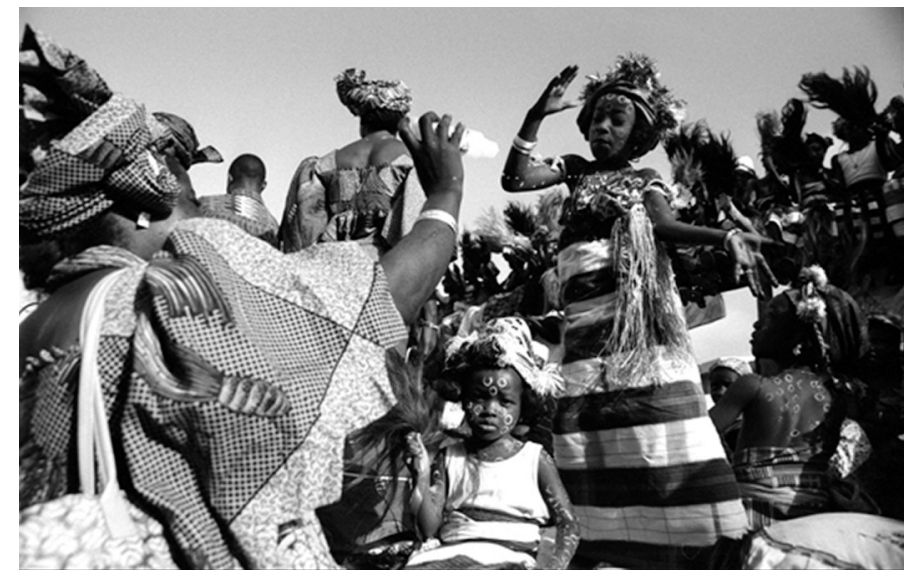

Figure 3. Unmarried girls in full dress, cheered at by their elder female siblings during Kouroubi dances (photo by Raymond Dakoua, Bondoukou, 25/3/2003). 
watches fall within the category of jewellery, while flashy tinsels add to the colourful effect of the gogoro.

To the extent that the outfits and attributes draw on what is claimed to be the repertoire of custom, the texts produced in the first register echo in a straightforward way traditional songs. These songs typically honour the different town quarters or their elders. However, the Donzo supremacy in the Sakaraboutou ritual is clear from the fact that the songs referring to the Donzo outnumber those addressed to the other neighbourhoods. Also in this register we find a number of songs that express the traditional joking relationships between different town quarters. In summary, the trajectory, the outfits, and the texts present, in a Durkheimian way, a Dyula-Muslim-centred, gerontocratic order legitimised by a selective tradition, geography and history. As we will see shortly, in the second register this order is not so much contested as supplemented and renegotiated in the performative elaborations of the youngsters, male and female alike.

Contrary to the apparent continuity and extraversion of the performative space in the first register, the space-time zone of the second register is discontinuous and more introvert. The space of the second register is constituted by the lapses of time or the bits of trajectory in between stopovers. During these moments male warriors and female 'Kouroubi' singers engage in (unequal) exchanges of lyrics. The call-and-response songs in which this takes place are introvert in that they are not directed to the audience of bystanders, even less so to the elders at the different stops, but to the 'youth constituency' of male and female participants. These verbal exchanges can be said to supplement the exchanges of items of decoration. The latter consist of Sakaraboutou warriors flaunting a number of attributes and items of body decoration that are explicitly female or 'Kouroubi'. The result of this is that a good part of the 'first line' male participants wear gogoro pompons, the jomo headpiece, and female make-up in combination with their traditional donzo outfit. Importantly enough, while in the case of attributes no such appropriations of other-gender items can be observed among girls, this is different when it comes to 'text' in the form of songs. In the vocal interaction that takes place in between greeting stops, the appropriation of tokens of femininity and masculinity is far more reciprocal.

The female and male youngsters have a small repertoire of songs in which they target each other as gender groups. Located in the inner core of the parade formed by the 'Kouroubi' girls, the small band of musicians, and a dozen or so Sakaraboutou warriors, intensive exchanges between 
both gender groups take place. One of the typical songs is the 'Wara wara song.' The (male-biased) standard version of this song is:

(lead) jamaná súnguru ju-o kálemara, i ka don young woman of the world anus (like) kalemara, you trample on it (chorus) ee wara wara

The kalemara is a small flask (d. bara) in glass, brass, calabash, or any other material, that is used to store fine coal powder (d. kale) used as eyeliner. In the song kalemara is signified as the female private parts (vagina, anus) and the 'trampling' as sexual intercourse. When time and circumstances permit, male and female singers engage in a dialogue whereby the girls transform the version of the song intoned by the boys, upon which the latter retaliate with still another variation, etc. One typical string of variations consists of a crescendo whereby the girls first replace súnguru (young girl) by kámele (young man), the boys then substitute kámele (young man) with musó (adult women); and the girls 'upgrade' their target from musó to masá (male chief):

(lead-girls) jamaná kámele ju kálenmara, i ka don

(lead-boys) jamaná musó ju kálenmara

(lead-girls) jamaná masá ju kálenmara

The interactive vocality and introvert spatiality of the second register creates a juvenile co-presence in terms of voice (dialogue) and space (proximity) which is perceived by many of the participants, including youngsters, as 'modern' in the sense of contemporaneous. This challenges time-honoured rules such as the one specifying that the tunics worn by Sakaraboutou warriors should not be touched by girls, hence, as the Sakaraboutou kuntigi, Baba Djéna, said to me: "in past times, there would be at least forty metres distance between the boys and the girls." ${ }^{n 4}$ With respect to the innovative character of the verbal exchange, one male youngster declared that:

In earlier times, the girls just repeated what the boys sang but nowadays the girls add words of their own; they even intone songs on their own initiative instead of waiting for the boys. ${ }^{55}$

More generally, the identification and powerplay that occurs in the different registers can be productively restated in terms of voice/identity and

\footnotetext{
54 Baba Djéna (12/02/1997).

55 Mahama Ouattara (28/05/2001).
} 
place/position. As already stated, in the first register the young warriors can be said to straightforwardly 'quote' tradition, not only in their costumes, attributes, and songs but also in their spatial operations. The tunics are said to be transmitted from the past to the present time through patrilineal filiation. This filiation underlies the only division that is allowed among the parading warriors: the one based on clan wards. This division in patriclans is played out in space as it defines the fixed greeting stops of the parade in the different town quarters. This grid of Dyula clan wards is extended to the non-Dyula groups whose chiefs receive the same vocal treatment as - and are thereby degraded to the status of - the different Dyula sub-chiefs. Finally, 'quoting' is also what the girls do in the parade. In their dresses, they replicate the 'traditional' unmarried girls' costume. In their songs the girls also quote the traditional songs but as they are not supposed to intone songs on their own initiative, their 'quoting' also has the character of 'echoing' the songs first started by the boys. This 'echoing' has a spatial dimension too in that they appear in the 'second line' of the parade, following the boys. ${ }^{56}$

In the second register the mode of articulation resembles closely the form of double-voicing which Rampton, following Bakhtin, characterises as "uni-directional." 57 In uni-directional double voicing, speakers use someone else's discourse for their own purposes but largely follow the latter's semantic intention. The vocal and material forms of double-voicing or 'crossing' are parodic in the sense that they are 'doubly coded'58 and constitute performances in which actors appropriate, explore, reproduce, or challenge influential images and stereotypes of groups and individuals other than their own. ${ }^{59}$ In visual instances of crossing, the Sakaraboutou boys engage in double-voicing by appropriating elements of clothing and decoration (jomo, gogoro, etc.) that are coded as tokens of femininity, not least during the Kouroubi performance that precedes the parade (Figure 4). In the re-coding of these tokens the gendered intention (i.e. 'I am a female' or 'this is female') is kept intact but is used to illustrate the male superior power and mobility to cross gender lines (and come back). In

56 As Regis, "Second Lines, Minstrelsy, and the Contested Landscapes of New Orleans Afro-Creole Festivals;" Regis, "Blackness and the Politics of Memory," explains 'second line' is another spatial-discursive register of the 'backstage' or the 'hidden transcript' kind which, if space was permitted, would deserve to be developed and compared with what happens in the Sakaraboutou parade.

57 Rampton, "Language Crossing and the Redefinition of Reality," 304.

58 Hutcheon, A Theory of Parody, 11.

59 Rampton, "Styling the Other: Introduction," 421. 


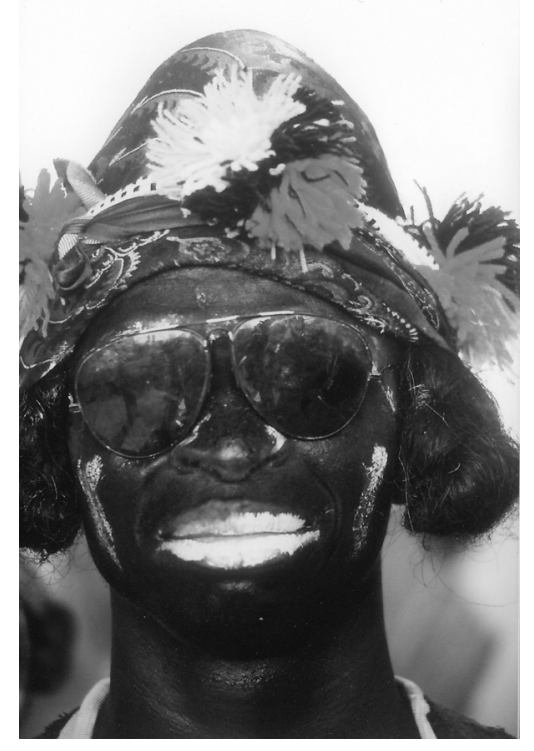

Figure 4. Typical second-register 'crossing': male warrior flaunting female Kouroubi-related attributes (photo by Karel Arnaut, Bondoukou, 13/03/1994).

the songs, very much the same happens. The boys 'lay their hands' (or rather 'stamp their feet') on items such as the kalenmara that are overdetermined as feminine. In terms of voice and space, this appropriation is effected through wordplay and allusions but above all through spatial proximity and even intimacy with the girls. In the second register, the spatial distance (both symbolically and materially) collapses into intimate proximity and direct reciprocity. This means that the girls respond to the boys' interventions by crossing into the domain of masculinity as radically as the boys invade their most intimate spaces. As said these crossings that constitute the second Sakaraboutou register are instances of reciprocal 'uni-directional double-voicing.'

In contrast, the mode of articulation that shapes the third register is 'vari-directional double-voicing,' in which the speaker radically redirects the semantic intention of someone else's discourse. ${ }^{60}$ This technique can be used for what Rampton and Hill call 'styling the other,' whereby a

60 Rampton, "Language Crossing and the Redefinition of Reality", 305. 


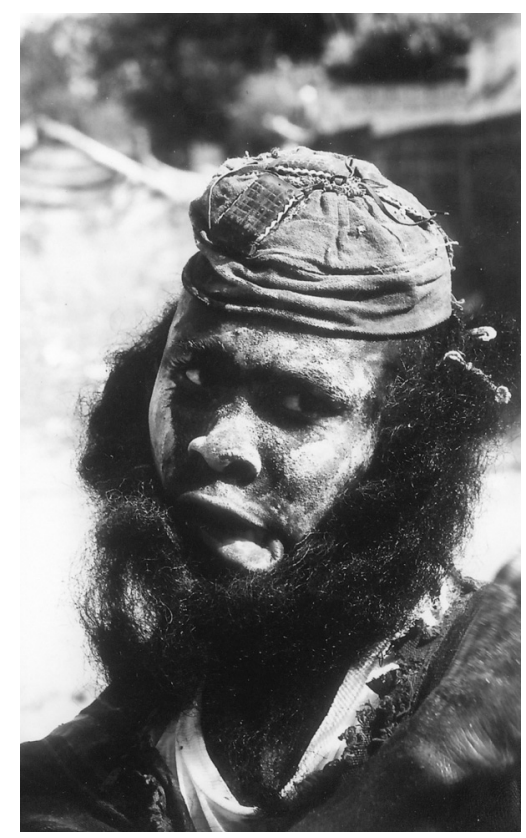

Figure 5. Sakaraboutou warriors with emblematic third-register features: multicolour face-paint, abundant body hair, and ugly grimaces (photo by Karel Arnaut, Bondoukou, 13/03/1994).

person engages in a complex identity play of selfing through othering. ${ }^{61}$ The setting for these complex operations of voicing and identification is a multitude of dispersed and often short-lived individual and smallgroup performances and impersonations that take place in the parade's periphery-in the spaces and moments somewhat removed from the main event and out of the focus of public attention.

In the third register one can distinguish two sorts of performances: (a) individual carnivalesque acts of impersonation and (b) what participants call the wanzu - a conglomerate of mock variants of religious (Muslim) communication including sermons, benedictions, and chants. In this chapter I only concentrate on the second form of performance, which takes place when a relatively small group of warriors detach themselves from the main/central group in order to stage a fragment of a wanzu, for instance in a lost corner of a compound which the parade visits. In

61 Rampton, “Styling the Other: Introduction;” Hill, "Styling Locally, Styling Globally.” 
terms of garments and make-up, the third register is the one in which the warriors transform their faces almost beyond recognition, either by making grimaces, using masks, or by adding excessive face hair and/or face paint-disguises which all contribute to the 'wild' appearance of the warriors and their composite identity as bush creatures (Figure 5).

The double voicing that takes place in the wanzu is exemplified by the way in which the standard Muslim benedictions and recitations are parodied. Among the most popular performances are those in which the benediction Ala si di i ma ('May God give you life') is systematically transformed using different parodic techniques such as line-initial and lineinternal repetition and substitution, alliteration, and rhyme resulting in variations such as Ala si di Ala ('may God give a long life to God') or ka di Ala na ma ('and give a long life to God's mother'). ${ }^{62}$ Also, in the side-performances of the third register Coran recitations are relexified in an even more radical way by substituting the religious texts with French cardinal numbers ranging from onze (11) to quinze (15), going sometimes up to seize (16). This gives the following recitation:

$\begin{array}{lll}\text { (lead) } & \text { kenzi, duzi } & (15,12) \\ \text { (chorus) } & \text { tirezi, katorzi } & (13,14) \\ \text { (lead) } & \text { onzi, duzi } & (11,12) \\ \text { (chorus) } & \text { tirezi, katorzi } & (13,14)\end{array}$

The vari-directionality of the double voicing that takes place in the wanzu first of all resides in the fact that the mock benedictions and recitations go against the semantic intention of the original. This is a far cry from the straightforward quoting (echoing) that goes on in the first register, or the reciprocal (even inimical) 'uni-directional double-voicing' of the second register. Together with these radical morphological and sematic subversions, the participants demonstrate their 'wildness' in extreme forms of discursive mobility in the mock sermons. The latter are microperformances which last only a couple of minutes and in which participants tell each other rather fanciful stories, while presenting themselves as half-pagans, and criticising the conduct of imams or Coran scholars. ${ }^{63}$ In wanzu we face a composite narrator who throughout the narrative uses

62 The terminology of parodic techniques utilised here is taken from Bauman's analysis of the performance of the masked figure of the Hermintaño in a Mexican colloquio, Bauman, "Transformation of the Word in the Production of Mexican Festival Drama"; see also Bauman and Ritch, "Informing Performance."

${ }^{63}$ Like the mock benedictions and recitations, these wanzu sermons are so problematic that they can hardly be mentioned in conversations with Muslim clerics or Sakaraboutou 
different voices/identities, of which a 'child,' a 'pupil,' and a 'world traveller' are the most common, together with that of 'bush creature.' The complex selfing/othering that goes on in the sermons results in a maelstrom of personae who are consistently quoting other people even as they speak for themselves. In this way the narrator refracts himself not only in multiple voices but also in multiple places. The marginal ritual terrain in which the Sakaraboutou bush creature operates is above all a 'multilocality' in a double sense: (a) as a non-place - a space of alterity, transformation, and transit or travel, ${ }^{64}$ and (b) in the sense of dispersed: 'everywhere' and 'all over the (local, national, and global) place.'

Conceiving what happens in the third register as performances of 'varidirectional double-voicing' helps us to get away from the idea that the male youngsters of the Sakaraboutou parade in a straightforward way criticise or attack Islam, its practices, institutions, and dogmas. Rather, the starting point of any appreciation of wanzu should be that Islam in the form of Islamic schools (their teachers and pupils), imams, unison recitations, recurring benedictions, as well as Ramadan-related sermons, form an important part of the immediate living environment of the youngsters. This provides the familiar discursive material and generic formats with which wanzu performers create 'alteric spaces' of national or global reach in which they claim for themselves uncertain and shifting places by controlling or manipulating (styling) the 'others' that inhabit them. ${ }^{65}$ At least, it should be clear that the juvenile bush creatures of the third register are far removed from the local Dyula warriors who follow in the steps of their fathers (first register) or from the naughty boys who excel in joking with members of the 'opposite' sex (second register). What is perhaps most puzzling about the third-register performances is that they are allowed to exist

officials, and if so, they are readily brushed aside as nonsensical child's play unworthy of proper Sakaraboutou warriors and-needless to say—scientific study.

${ }^{64}$ Cf. Augé, Non-lieux; Argenti, "Air Youth."

65 This is not the place to extensively theorize 'inhabit' as a concept. Nonetheless its general sense is perhaps best expressed in Henrietta Moore's statement about how people deal with, or rather try to appropriate, multiplicity: "Fragmentation, multiplicity, ambiguity, diaspora, and disjuncture are one way of imagining people and their lives, [...] but not the only one. For all of this, people still live in communities, inhabit spaces, feel themselves to be acting agents, take control over their lives, and experience intimacy, and consistency and inhabit life projects"; Moore, "The Future of Gender or the End of a Brilliant Career," 27. In general, the concept of inhabiting is often used when dealing with issues of belonging in a rapidly transforming world (cf. Inda and Rosaldo, "Tracking Global Flows.") or in situations of marginality (Das and Poole, "Introduction: State and Its Margins," 6). 
in the first place, that they are given the minimal breathing space, however dispersed and peripheral, to spout their anti-establishment nonsense.

\section{Concluding Remarks: Sabotage, Complicity, and the Future of Tradition}

Within a single parade, a complex polyphony of voice, dance, wordplay, and all manner of embodied signifying are on display. Its massive complexity is elusive, resisting distillation into a single message or a unitary image.... ${ }^{66}$

This paper set out to work towards substituting a 'sociologizing' with a 'performative' approach to public ritual. This consists of (a) exploring the heterogeneous ways in which different ritual constituencies realize, extend, or complement the 'formulaic spatiality' of a ritual performance, and (b) considering these formulations as elements of power plays that work with, add to, reflect upon, or redirect, established power relations in society at large. De-sociologizing ritual performance thus means not only destabilizing the relationship between ritual performance and pre-existing scripts as Fabian suggests, but also looking beyond the monosemic links between performance and society as Erlmann demands. Both postDurkheimian interventions, in a sense, open the necessary 'space' that our concept of register-as constellation of modes of expression and replication, as roles/identities, and as ways of inhabiting space-tries to occupy.

In the end, the present case-study of the Sakaraboutou public ritual seeks to support and develop Kapferer's general claim that public rituals do "not simply represent the wider reality; they [are], through their participants, 'structurating' processes, vital in the construction and reconstruction of lived realities." 67 This conclusion was launched by Kapferer in a re-study of Clyde Mitchell's Kalela dance in which the latter is presented as the festive space in which urban identities were being articulated performatively. In the dance, the Copperbelt urbanites not only staged authority figures ('nurse,' 'doctor,' 'customary chief') of quotidian colonial practice, Kapferer argues, but they also pictured themselves as

${ }^{66}$ Regis, "Second Lines, Minstrelsy, and the Contested Landscapes of New Orleans Afro-Creole Festivals," 482.

67 Kapferer, "The Performance of Categories," 77. 
seen through the eyes of the colonial order, that is, as tradition-bound and stereotyped. ${ }^{68}$ Therefore, Kapferer finds it paradoxical that "the African mirroring of colonial practice was conceived by the colonizers as the persistence of tribal practice and sentiments." 69

The same can be said of the Sakaraboutou youngsters who, in the conversations I had with them, realise the license they enjoy in 'mirroring' their life-world of everyday, topical, and sexual as much as economic, religious and geopolitical concerns and anxieties. They realise that such is possible in a public performance that is the object of as much disciplining and monitoring as the urban religious traditional custom of Sakaraboutou. In that sense also, the present study is not new and reiterates the mantra of contemporary anthropology that 'tradition' is not only represented but reconstructed and reinvented through performance. ${ }^{70}$ Paraphrasing Ranger, one could summarise the present analysis as an attempt to regard performances as dynamic under the guise of traditionalism and semi-autonomous from hegemonic society. ${ }^{71}$

What is arguably special about the present analysis is that it explicates both the 'dynamic,' 'the traditionalism,' and the 'guise' in performative terms: in the visual expressions, the complex discursive operations, as well as the spatial and voicing tactics of the multiple ritual constituencies. This shows how the complicity, particularly between youngsters and elders, forms a key element in the governance by spectacle that is realized through Sakaraboutou. For all its unruliness, the strange infantry (lit. children's army) that is the Sakaraboutou cortege does not threaten the Dyula-Muslim gerontocratic order because the representation of that order forms the 'guise,' the alibi, or the occasion, to shape alternative or supplementary juvenile orders. Put in the terms proposed by Scott and Goffman, Sakaraboutou is an assemblage of more or less public and more or less hidden transcripts, a complex of overlapping frontstage and backstage regions. Each of these can be seen as alternative spatial and performative formulations. These formulations, in their turn, address or create spaces of other scales and magnitude than the 'urban' space defined in the first register: the space of sexual intimacy in the second register and

68 Kapferer, "The Performance of Categories," 64-5.

69 Ibid., 67.

70 Ranger, "The Invention of Tradition"; Brightman, "Traditions of Subversion and the Subversion of Tradition"; Silverstein and Urban, "The Natural History of Discourse."

71 Ranger, "The Invention of Tradition Revisited," 101-2. 
the 'global' space of national and international geopolitics in the third register. Arguably, without this multidimensional or multiscalar saliency any local custom would be condemned to disappear. Future Bondoukou urbanites may make space for Sakaraboutou to the extent that Sakaraboutou makes space for them, their personal and global dreams and anxieties. 
Devising Order 


\title{
Brill's Series in \\ Church History
}

\author{
Edited by \\ Wim Janse, Amsterdam
}

In cooperation with

Theo Clemens, Utrecht/Antwerpen

Paul van Geest, Amsterdam/Tilburg

Alastair Hamilton, London

R. Ward Holder, Manchester, NH

Scott Mandelbrote, Cambridge, UK

Andrew Pettegree, St. Andrews

VOLUME 60

\section{Religious History and Culture Series}

\author{
Edited by \\ Joris van Eijnatten, Utrecht \\ Fred van Lieburg, Amsterdam
}

VOLUME 7 


\title{
Devising Order
}

\author{
Socio-religious Models, Rituals, \\ and the Performativity of Practice
}

\author{
Edited by \\ Bruno Boute \\ Thomas Småberg
}

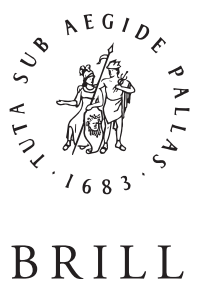

LEIDEN • BOSTON 
Cover illustrations in clockwise order:

1. The Chief Warrior (d. kuntigi) leading the Sakaraboutou Parade at Boundoukou, Côte d'Ivoire (Photo by Karel Arnaut, Boundoukou, 13/03/1994)

2. A wonderful play: Dutch children playing the Catholic Mass in the Catholic Review De Engelbewaarder, 29 (1913), 734 (Katholiek Documentatiecentrum Radboud Universiteit Nijmegen) 3. Portrait of Gregorio Lopez (Luo Wenzao), Vicar Apostolic of China, in Louis Le Comte, Nouveaux Memoires de la Chine, Amsterdam: Henri Desbordes and Antoine Schelte, 1698, vol. 2, plate following page 171 (Houghton Library, Harvard College Library. Ch $62.33 .8^{*}$ )

4. Modern pilgrimage at spring equinox at the Kuculkan pyramid, Chichen Itzá, Yucatán, in

Mexico (Photo by Bodil Liljefors Persson, 21/03/2005)

Library of Congress Cataloging-in-Publication Data

Devising order : socio-religious models, rituals, and the performativity of practice / edited by Bruno Boute, Thomas Småberg.

p. cm. - (Brill's series in church history, ISSN 1572-4107 ; volume 6o. Religious history and culture series ; volume 7 )

Includes bibliographical references and index.

ISBN 978-90-04-23674-5 (hardback : alk. paper)—ISBN 978-90-04-240o3-2 (e-book)

1. Rites and ceremonies. 2. Ritual. 3. Religion and sociology. I. Boute, Bruno. II. Småberg,

Thomas, 1970-

BL6oo.D48 2013

$203 \cdot 8-\mathrm{dc} 23$

This publication has been typeset in the multilingual "Brill" typeface. With over 5,10o characters covering Latin, IPA, Greek, and Cyrillic, this typeface is especially suitable for use in the humanities. For more information, please see www.brill.com/brill-typeface.

ISSN 1572-4107

ISBN 978-90-04-23674-5 (hardback)

ISBN 978-90-04-24003-2 (e-book)

Copyright 2013 by Koninklijke Brill NV, Leiden, The Netherlands.

Koninklijke Brill NV incorporates the imprints Brill, Global Oriental, Hotei Publishing, IDC Publishers and Martinus Nijhoff Publishers.

All rights reserved. No part of this publication may be reproduced, translated, stored in a retrieval system, or transmitted in any form or by any means, electronic, mechanical, photocopying, recording or otherwise, without prior written permission from the publisher.

Authorization to photocopy items for internal or personal use is granted by Koninklijke Brill NV provided that the appropriate fees are paid directly to The Copyright Clearance Center, 222 Rosewood Drive, Suite 910, Danvers, MA 01923, USA.

Fees are subject to change.

This book is printed on acid-free paper. 


\section{CONTENTS}

Notes on Contributors .............................................................................. vii

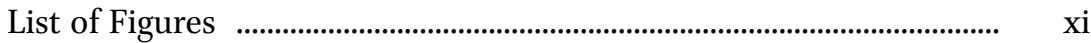

Introduction: Devising Order. Socio-religious Models, Rituals, and the Performativity of Practice ………………………………….... 1 Bruno Boute and Thomas Småberg

The Priest, the Sexton, and the Weaver: A Flemish Dinner Play Performing Biblical Theology (c. 1539-1565) $\quad$...................................... 19 Wim François

Death as the Guest of Honour: The Social Constructions of Funeral Rites in Southern Sweden, 1880-1949 Anna Stark

Giving Public Space a Face: The Agency of Monuments and Portraits, Thailand and the Netherlands Compared Irene Stengs

Making Space for Performativity: Publics, Powers, and Places in a Multi-Register Town Festival (Bondoukou, Côte d'Ivoire) Karel Arnaut

Place, Power, and Prophecy: Ritual Space and Speech among the Yucatec Maya from Colonial Time to Present Time 103 Bodil Liljefors Persson

Reinventing the Apostolic Tradition: Transition and Appropriation in the Medieval Commemoration of the Apostles Els Rose

Affirming Papal Supremacy_Shaping Catholicism: The Readjustment of Symbolic Resources at the Post-Trent Roman Court Julia Zunckel 
The Ritual Battle of Tournament: Tornej, Dust, and Bohord in Medieval Sweden ca. 1250-1320 165

Thomas Småberg

European and Chinese Controversies over Rituals:

A Seventeenth-Century Genealogy of Chinese Religion 193 Eugenio Menegon

Engineering the Sacred: Perspectives for Research into Sacramental Practice and Conflicts over Sacraments in the Seventeenth Century 223 Bruno Boute

The Jesuit Ordering: In Between the Imaginative Force of the Art of Memory and the Organizational Power of Accounting Practices Paolo Quattrone

Concluding Remarks: Rituality, Performativity, History, and Religion 265 Joris Van Eijnatten

Bibliography 271 Index 


\section{NOTES ON CONTRIBUTORS}

Karel Arnaut, Ph.D. in Anthropology (2004), University of Ghent, is a researcher at the Max-Planck-Institut zür Erforschung multireligiöser und multiethnischer Gesellschaften at Göttingen, Germany. He studied at Ghent, Utrecht, and Oxford and taught at the Department of African Languages and Cultures (Ghent University, Belgium). He publishes on political, cultural, and religious performance by youth groups in Côte d'Ivoire or by Ivoirians in the diaspora. Some of his work is on the presentation and staging of Africans in Europe from the late nineteenth century until the present.

BRuno Boute, Ph.D. in History (2003), Catholic University of Leuven, is a researcher at the Westfälische Wilhelms-Universität Münster, Seminar für Mittlere und Neuere Kirchengeschichte, Germany. He publishes on religious history, history of the papacy, and the history of universities in early modern Europe.

Wim François, Ph.D. in Theology (2004), Catholic University of Leuven, is a Research Professor at the Catholic University of Leuven, Research Unit History of Church and Theology, Belgium. He publishes on vernacular Bible reading and the Augustinian inspiration of the Louvain theologians' Bible commentaries in the Early Modern Era, in addition to the mission history of Leopold II's Congo (c. 190o).

Bodil Liljefors Persson, Ph.D. in History of Religion (2000), Lund University, is Associate Professor at Malmö University, Faculty of Education and Society, Department of History, Religious Studies, and Social Science, Sweden. She publishes on Maya religion and history from early Colonial times and contemporary times as well as on ritual studies, cultural encounters, religion, didactics, and citizenship education.

Eugenio Menegon, Ph.D. in Chinese History (2002), University of California at Berkeley, is Associate Professor at Boston University, Department of History, USA. He publishes and teaches on late imperial Chinese history, history of Chinese-Western relations, and world history. 
Paolo Quattrone, Ph.D. in Business Economics and Management (1996), Università degli Studi di Catania, is Professor of Accounting and Management Control at IE Business School, Madrid, Spain. He has published widely on the genesis of accounting and administrative practices, with particular attention to the role of religious organizations such as the Jesuit Order, and on the managerialisation of higher education institutions.

Els Rose, Ph.D. in Medieval Latin (2001), Utrecht University, is Associate Professor of Medieval Latin at Utrecht University, The Netherlands. She publishes on early medieval liturgy, medieval cults of the saints, and particularly on textual and pictorial transmission of the apocryphal Acts of the Apostles (Virtutes apostolorum) in the Middle Ages.

Thomas SmÅberg, Ph.D. in History, (2004), Göteborg University, is Lecturer in History and History Teaching at Malmö University, Sweden. He has published on social networks and friendship in the Middle Ages, and is currently conducting research on Swedish medieval ritual and gender.

ANNA STARK, MA in History (2004), Lund University, is a postgraduate student at Linnaeus University, Växjö, Sweden. She conducts research in Death Studies, Gender Studies, and Cultural History.

Irene Stengs, Ph.D. in Cultural Anthropology (2003), University of Amsterdam, is a Senior Researcher at the Meertens Instituut in Amsterdam, The Netherlands. She has published on modernity, social imaginary, and Buddhist kingship in Thailand, and on public mourning rituals, dance culture, and local identities in The Netherlands, with a special interest in the way media, culture, and individual politics are interrelated in contemporary societies.

Joris VAn Eijnatten, Ph.D. in History (1993), VU University Amsterdam, is Professor and chair for cultural history at Utrecht University, The Netherlands. He publishes on religious history, the history of ideas, and the history of media and communication.

Julia Zunckel, Ph.D. in History (1995), Freie Universität Berlin, is a researcher at the Westfälische Wilhelms-Universität Münster, Sonderforschungsbereich of the German Research Council 496 Symbolische Kommunikation und Gesellschaftliche Wertesysteme, Germany. She publishes 
on socioeconomic history (especially on the republic of Genoa and the weapons and gunpowder trade in the Thirty Years' War), on the ecclesiastical history of Milan (especially on the cardinal-archbishop Federico Borromeo), and on the sociopolitical and cultural history of the early modern Papacy. 



\section{LIST OF FIGURES}

\section{Irene Stengs}

1. King Bhumibol Adulyadej's portrait on Ratchadamnoen Avenue, one of many, in honour of the king's 8oth birthday in 2007 (photo by Irene Stengs, 12/01/2008)

2. Well-wishing billboard for King Bhumibol Adulyadej at a mountain road in Chiang Mai province (photo by Irene Stengs, 20/01/2010)

3. Yellow Ambi Pur plug-in air fresheners, limited 8oth Royal Birthday edition (photo by Irene Stengs, 20/01/2008)

4. The Ted Alfrink memorial in the first weeks after Ted's death (http://www.ted-alfrink.net)

5. The Ted Alfrink memorial on December 18, 2003, around 6 PM, all candles were lit (photo by Irene Stengs, 18/12/2003) ... $\quad 75$

6. 'Future comfort tears', the Young Road Traffic Victims Monument (http://www.monument-nuenen.net)

\section{Karel Arnaut}

1. The chief warrior (d. kuntigi) leading the Sakaraboutou parade, accompanied by female singers and a band of male musicians (in the background) (photo by Karel Arnaut, Boundoukou, 13/03/1994)

2. Male youngsters mostly in 'traditional' outfit and warrior-hunter's offensive and defensive attributes during Sakaraboutou parade (photo by Filip Erkens, Bondoukou, 9/02/1997)

3. Unmarried girls in full dress, cheered at by their elder female siblings during Kouroubi dances (photo by Raymond Dakoua, Bondoukou, 25/3/2003) 
4. Typical second-register 'crossing': male warrior flaunting female Kouroubi-related attributes (photo by Karel Arnaut, Bondoukou, 13/03/1994)

5. Sakaraboutou warriors with emblematic third-register features: multi-colour face-paint, abundant body hair, and ugly grimaces (photo by Karel Arnaut, Boundoukou, 13/03/1994)

\section{Bodil Liljefors Persson}

\section{Figures}

1. The Convent and church in Mani (photo by Bodil Liljefors Persson, 18/03/2005) ....................................................................................... 108

2. Chichen Itzá (photo by Bodil Liljefors Persson, 21/03/2007)

3. Cabal chen, the cave where Chilam Balam was a singer, Mani (photo by Bodil Liljefors Persson, 18/03/2005)

4. Santuario de la cruz parlante, Felipe Carillo Puerte (photo by Bodil Liljefors Persson, 18/03/2007)

Table

1. Synoptic Overview of Texts Referred to in this Chapter

\section{Thomas Småberg}

1. Tournament seen on church door, Södra Råda church, Sweden, fifteenth century (source: Riksantikvarieämbetet) ......... $\quad 176$

\section{Bruno Boute}

1. The Management Cycle of Salvation 238

2. The Technological Cycle of Salvation 238 